with the disease were introduced. With colonies of 27 and 30 tame, and 55 and 44 wild, rabbits, the fatality was $99 \cdot 6$ per cent among the tame, and 100 per cent among the wild. The disease originally came from epizootics among tame rabbits in South America.

\section{Research at Millport}

The Annual Report of the Executive to the Council of the Scottish Marine Biological Association for 1934-35 includes the director's report on research. Drs. Orr, Marshall and Nicholls are concentrating on the development and food of the herring from hatching onward. In this connexion, it is found that copepods are by far the most important food organisms, the larval and post-larval herring eating chiefly the small species. In view of this fact, it was decided to investigate seasonal distribution and breeding periods of these small copepods, in the same way as has already been done for Calanus finmarchicus. Results so far show that in the early months Microcalanus pusillus and Oithona helgolandica were the most abundant species, with Pseudocalanus elongatus, Centropages hamatus, Temora longicornis and Acartia clausi occurring in smaller numbers. Most of the important planktonic organisms have been weighed, and in some cases the chemical composition determined. During the winter, when zooplanktonic organisms are scarce, a beginning was made on the analysis of non-planktonic animals important as fish food. Investigations on shore ecology, especially in Kames Bay, by Dr. A. C. Stephen and Mr. Elmhirst, have been continued. The work already done has shown a very rich fauna important for fish food. Various fishes from the seine net have been examined and shown to feed on the dominant invertebrates. A very interesting feature in these investigations is the work by Dr. Nicholls on sand-dwelling copepods, especially minute species living in the interstices between the sand grains on the beach. Several new species of these and three new genera have been found. Other researches include algal ecology and preserving colour in green seaweeds, experiments on timber preservation in the sea and the growth of the dog-fish Acanthias.

\section{Seismology in New Zealand}

THE report of Dr. C. E. Adams, Dominion Astronomer and Seismologist, for the year 1934 (Dept. Sci. Indus. Res. Bull., No. 105) shows that the seismic activity of New Zealand was much greater during that year than in 1933, the number of earthquakes felt being 230 , instead of 108 . Of these, 158 were felt in the North Island only, 60 in the South Island only, and 12 in both islands. The most important shock was that of March 5 at 11.16 p.m. N.Z. time (11.46 a.m., G.M.T.). Its intensity in several parts of northern Wairarapa reached the degree 9 of the Rossi-Forel scale and chimneys fell over a wide area in the southern part of the North Island. The map that accompanies the paper shows that most of the epicentres lay in the extreme north of South Island and the southern half of North Island. Owing to the increased activity off the east coast of the latter island and to other changes that have been reported along the coast, it is strongly recommended that a detailed marine survey should be carried out of the whole east coast, including soundings in the seas to the east of New Zealend.

\section{Solar Activity and Terrestrial Phenomena}

Is 1924 the International Research Council (now transformed into the International Council of Scientific Unions) formed a Commission for the Study of Solar and Terrestrial Relationships, a field of science which extends over the domains of at least three of the International Scientific Unions. This Commission, among other activities, has published triennial reports, reviewing the state and progress of knowledge on solar and terrestrial relationships, and, where necessary, making recommendations regarding action that may conduce to further progress. These reports are distributed to certain libraries and to institutions and individuals occupied in work relating to the subject. The fourth report has recently been issued (Conseil International des Unions Scientifiques : Quatrième Rapport de la Commission pour l'Etude des Relations entre les Phénomènes Solaires et Terrestres; pp. 159. Firenze, 1936) under the editorship of the president of the Commission, Prof. G. Abetti, Astrophysical Observatory, Arcetri, Italy. It differs from its predecessors in being better and more attractively produced, and in having a valuable 28-page introduction by the editor, giving a general survey of the subject for the past three years. The remainder of the volume consists of twenty-one brief articles on different aspects of the subject, by various authors.

\section{Electric Supply in the Irish Free State}

THE annual report of the Electricity Supply Board of the Irish Free State for the year ending March 31, 1936 shows that a further increase in the sale of electricity has been effected, and results in a surplus of income over expenditure of about $£ 310,000$. The total capital expenditure is now about $10 \frac{1}{2}$ million pounds, of which 5 per cent is paid to the State. The total sale of electric units during the year amounted to 187 millions, and the average receipts per unit dropped from $1 \cdot 92 d$. to $1 \cdot 84 d$. The figures show a very satisfactory acceleration in the development of the consumption of electricity for domestic purposes. In the environs of Dublin the consumption increased by 63 per cent. The total units generated during the year were 243 millions, of which 211 millions were supplied by the hydro-electric power station on the Shannon. Details are given of the extension of plant, and the building of new works on the Shannon and at the Pigeon House in Dublin. Two Swiss experts have reported on the development of the River Liffey for hydro-electric purposes. As it is the intention of the Corporation of the City of Dublin to use the water-storage reservoir on the Liffey to augment the ordinary water supply to the city, it was found inadvisable to take full advantage of the Liffey water-power project for six or seven years. As soon as the necessary legislative provision has been obtained, the work on the reservoir will be 